\title{
Preventing Islamic Radicalism Through Integrative Epistemology of Sadrian Philosophy: The Case Study of Hizbut Tahrir Indonesia's Reasoning
}

\author{
Fadhlu Rahman \\ Sekolah Tinggi Filsafat Islam Sadra \\ gt630111@gmail.com
}

\author{
Pia Nuraripah \\ Sekolah Tinggi Agama Islam Al-Azhary \\ pianuraripah@gmail.com
}

\section{Rahmatika Layyinah}

Universitas Islam Indonesia

tika.layyiinah@gmail.com

\begin{abstract}
Abstrak: Intolerance and radicalism in Indonesia achieve dangerous staging status. This condition in individual aspects have an influence on the way of view that will tend to be defensive, apologist and pessimistic in religion. This also becomes the initial cause for the birth of social, political and educational implications. HTI (Hizbut-Tahrir Indonesia) is a radical mass organization that is quite influential in Indonesia. The epistemological problem related to the theory of knowledge is one of the important and fundamental factors in the emergence of understanding and various acts of radicalism in HTI, where it only recognizes thinking by relying on factual objects as the only valid knowledge that leads to empiricism and materialism so that it rejects the form of spiritual knowledge that is able to accept diversity in opinion. In addition to these fundamental reasons, Sufism is also often considered to be heretical because it is not committed to the Qur'an and Sunnah. It is thus necessary for an integrative understanding between the three epistemological
\end{abstract}


Fadhlu Rahman, dkk.

elements (Textual, spiritual, and rational) as the building blocks of deradicalization in religion as well as a strong commitment to the Qur'an and al-Sunnah. A descriptive analysis of Mulla Sadra's epistemology as a philosopher and Sufi can be one of the cornerstones of criticism as well as a solution to the problem of HTI's radical epistemology. This is reflected in the integration of the three methods (textual, spiritual and rational) which he uses as a way of knowing the nature of things. Thus, the thesis that we can propose is to use Sadra's integrative epistemology in gaining knowledge will avoid an understanding of HTI's radicalism.

Abstrak: Intoleransi dan radikalisme di Indonesia mencapai status kondisi berbahaya. Kondisi seperti ini dalam aspek keindividuan berpengaruh pada cara pandangnya yang akan cenderung defensif, apologis dan pesimistis dalam beragama. Ini sekaligus menjadi sebab awal bagi lahirnya implikasi-implikasi sosial, politik dan pendidikan. HTI (Hizbut Tahrir Indonesia) adalah Ormas radikal yang cukup berpengaruh di Indonesia. Problem epistemologis yang berkaitan dengan teori pengetahuan menjadi salah satu dari sekian faktor penting dan mendasar munculnya pemahaman serta berbagai tindakan radikalisme HTI, dimana ia hanya mengakui berfikir dengan berpijak pada objek-objek faktual sebagai satu-satunya pengetahuan valid yang berujung pada sikap dan cara pandang empirisme dan materialisme sehingga menolak bentuk pengetahuan spiritual yang mampu menerima keberagaman dalam berpendapat. Selain alasan mendasar tersebut, tasawuf juga sering dianggap mereka sesat karena tidak berkomitmen pada al-Qur'an dan Sunnah. Ini sehingga perlu sebuah pemahaman integratif antara ketiga elemen epistemologis tersebut (Tekstual, spiritual, dan rasional) sebagai basis pembangun deradikalisasi dalam beragama sekaligus komitmen kuat pada al-Qur'an dan al-Sunnah. Analisis deskriptif pada epistemologi Mulla Sadra sebagai filosof sekaligus sufi Islam dapat menjadi salah satu pijakan kritik sekaligus solusi atas problem epistemologi radikalisme HTI. Ini tercermin pada integrasi tiga metode (tekstual, spiritual dan rasional) yang digunakannya sebagai jalan mengetahui hakikat segala sesuatu. Dengan demikian, tesis yang dapat kami ajukan adalah menggunakan epistemologi integratif Sadra dalam memperoleh pengetahuan dapat menghindari pemahamanpemahaman radikalisme.

Kata kunci: Materialistic Empiricism, Integrative Epistemology, HTI, Deradicalization 


\section{A. Introduction}

Intolerance and radicalism in Indonesia achieve dangerous staging status. The center for the Study of Islam and Society (PPIM) UIN Syarif Hidayatullah conducted research in 34 provinces in 2017 in Indonesia related to opinions and actions of intolerance and radicalism of students and lecturers / teachers. The results of his research show that at the level of opinion, students tend to have an intolerant religious outlook. They proved this from the distribution between radical opinion, external tolerance, and internal tolerance of students. Of the three categories, the most intolerant religious views are found in radical opinion $(58.5 \%)$ followed by internal intolerance opinion (51.1\%) and external intolerance opinion (34.3\%). While at the level of action students have religious behavior that tends to be moderate / tolerant. This is found in at least a percentage of radical actions, which is only $7.0 \%$ and the action of external intolerance is $17.3 \%$. However, the action of internal intolerance tends to be higher, which is $34.1 \%$. While at the lecturer/ teacher level, they tend to be tolerant in terms of opinion or understanding, but intolerant from the side of the action with evidence of lower internal intolerance opinions, namely (33.9\%), external intolerance opinion (29.2\%), and radical opinion $(23.0 \%)^{1}$.

This conditions in individual aspects have an influence on the way of view that will tend to be defensive, apologist and pessimistic in religion. This also becomes the initial cause for the birth of social, political and educational implications ${ }^{2}$. On the aspects of education, radicalism and tolerance lead to a rigid understanding of religion, this is also a reason for the decline of the intellectual dimension of Islam:

the neorevivalist is, by contrast, a shallow and superficial person-really rooted neither in the Quran nor in traditional intellectual culture, of which he knows practically nothing. Because he has no serious intellectual depth or breadth, his consolation and pride both are to chant his consolation and

${ }^{1}$ PPIM (Pusat Pengkajian Islam dan Masyarakat), Survey Nasional tentang Sikap keberagamaan di Sekolah dan Universitas di Indonesia (Jakarta: PPIM UIN Jakarta, 2017), p. 3.

${ }^{2}$ Lufaefi, "Rekontruksi Jargon Formalisasi Syari'at: Upaya Menjaga Kesatuan dalam Bingkai Keberagamaan”, Journal of al-A'raf, vol. 14, no. 1, (2017), p. 77-78 
pride both are to chant ceaselessly the song that Islam is "very simple" and "straight forward;' without knowing what these words mean ${ }^{3}$.

While at a certain level on the social and political aspects radical understanding seeks to realize a state order, that is considered to have realized God's laws and rejected ideologies other than that. ${ }^{4}$ In the aspect of Indonesian-ness nationalism, this country is considered as a system that destroys the Khiläfah Islämiyah system, because according to him the essence of Indonesia is the possession of Allah and must be realized by Allah's law in the form of Khilāfah:

From the national dimension, the ideology of terrorist can be traced from Abdullah Sungkar teachings. He asserted that islam never teaches nationalism, so that there is no Indonesian country in islamic concept. He perceived that the universe, where Indonesia is in belongs to Allah. He also argues that the naming of Indonesia was a coincidence as this country is located between Melanesia and India ${ }^{5}$.

This would later become the argument for justification for actions which at some level caused victims with bombings to realize their main vision of establishing a Khilā fah Islāmiyah state.

In the context of the Indonesian state, HTI (Hizbut-Tahrir Indonesia) is a radical mass organization that is influential in Indonesia. Even though these mass organizations have been structurally dissolved and banned in Indonesia ${ }^{6}$, they still leave their thought which is reflected in their followers. The strategy for disseminating his understanding according to Osman has made HTI an organization that can have a harmful effect on the long term "Today, HTI is growing in influence and popularity. Its ability to effect change despite its small size will have long-term effect on

${ }^{3}$ Fazlur Rahman, Islam and Modernity, (Chicago: Chicago University Press. 1962), p. 137.

4 Fathul Mufid, "Radikalisme Islam dalam Perspektif Epistemologi", Journal of Addin, vol. 1. no. 10. (2016), p. 4. See also Bassam Tibi, Islamism and Islam, (London: Yale University Press 2012), p. 31.

${ }^{5}$ Sri Yunanto \& Anggel Damayanti, "The Root and Causes of Nexus Militant Islamic Movements in Indonesia: Case Studies of Darul Islam and Jemaah Islāmiyah", Journal of Asia Pacific Studies. vol. 1. no. 1. (2017), p. 31.

${ }^{6}$ Ihsanuddin, Jalan Panjang Pemerintah Bubarkan HTI, Kompas. 8 Mei 2018 
Indonesian politics. It is likely that the emergence of more issues related to role of Islam in Indonesia will result in the strengthening of HTI. $^{7}$

The epistemological problem related to the theory of knowledge is one of the important and fundamental factors in the emergence of understanding and various acts of radicalism in HTI. This is because philosophically an understanding is formed by how it gets knowledge ${ }^{8}$. The knowledge gained by HTI epistemologically rejects all forms of non-factual knowledge, meaning that all knowledge and understanding that is not sensory based in its acquisition are not recognized as knowledge but are illusory and even categorized as irrational knowledge as Taqiyuddin al-Nabhani in alTafkir translated by Taqiyuddin as-Sibā'i:

"Proses berpikir hanya mungkin terjadi pada suatu fakta atau sesuatu yang mempunyai fakta artinya, proses berpikir tidak bisa berjalan pada selain fakta yang terindera. Sebab, aktivitas berpikir merupakan proses memindahkan fakta melalui panca indera ke dalam otak. Oleh karena itu, jika tidak ada fakta yang diindera, aktivitas berpikir tidak mungkin bisa dilakukan". ${ }^{9}$

Epistemologically the consequences of only accepting sensory knowledge as its basis culminate in the perspective of empiricism and materialism, so that it rejects the form of spiritual knowledge that is capable of accepting diversity in opinion while giving rise to problems in placing rationality. However, their commitment to the sacred text and sunnah needs to be considered as a form of excellence that they offer in understanding religion ${ }^{10}$, even though it contradicts the way of thinking and attitude. It is thus necessary for an integrative understanding between the three

${ }^{7}$ Mohamed Nawab \& Mohamed Osman, Reviving the Caliphate in the Nusantara: Hizbut Tahrir Indonesia's Mobilization Strategy and Its Impact in Indonesia, (Singapura: Nanyang Technological University. 2009), p. 33.

${ }^{8}$ Donald. M. Borchert (ed.), Ecnyclopedia of Philosophy, (New York: Thompson Gale. 2006), p. 270. See also Taqi Misbah Yazdi, Philosophical Instruction: An Introduction to Contemporary Islamic Philosophy, (New York: Global Publication, 1999), p. 85.

${ }^{9}$ Taqiyuddin An-Nabhani, Al-Tafkir yang diterjemahkan oleh Taqiyuddin As-Sibā'I, (Bogor: Hizbut Tahrir. 1973), p. 21.

${ }_{10}$ Taqiyuddin An-Nabhani, Mafähim At-Tafkir yang diterjemahkan oleh Abdullah (Jakarta: Hizbut Tahrir. 2001), p. 64. 
epistemological elements (Textual, spiritual, and rational) as the building blocks of deradicalization in religion.

A descriptive analysis of Mulla Sadra's epistemology as a philosopher and Islamic Sufi can be one of the cornerstones of criticism as well as a solution to the problem of HTI's radical epistemology. This is reflected in the integration of the three methods (textual, spiritual and rational) which he uses as a way of knowing the nature of things. ${ }^{11}$

With this, the thesis that we can propose is to use Sadra's integrative epistemology in gaining knowledge will avoid radical understanding of HTI.

\section{B. The Concept and Spirituality Values}

The discussion of concepts and values of spirituality became important in this study given the need to agree on what later became one of the main discourses in Sadrian's epistemological debate and radicalism in measuring spiritual experience. In Latin spirituality comes from the word spirit which means spirit, soul, soul, form that is without body, breath, or life. Spiritual means mental, spiritual, and moral. Whereas spirituality is a process to reach the highest peak consciousness. From these three syllables we can trace the meaning of spirituality as a process to achieve self-actualization based on or driven by spiritual power ${ }^{12}$. This means that things that are at the core of self-actualization power come from spiritual substances. This spiritual substance is emphasized by Nasr in In Search of the Sacred "spirituality is to be in contact with the world of the spirit and that transcends all particularities of the human state and of the materal world" 13 .

This spiritual thing becomes a dimension in man. Spirit is a core reality of humans. From it all the power of human potential is obtained. Irham Iqbal in his dissertation put the position of Spirit as the genus of the soul. the reality is directly related to Divine aspects,

${ }^{11}$ Haidar Bagir, Pengantar Epistemologi Tasawuf, (Bandung: Mizan. 2017), p. 89.

${ }^{12}$ Muhammad Iqbal Irham, Menghidupkan Spiritualitas islam: Kajian terhadap Konsep Hudūr Ibn Arabi, (Jakarta: Semesta), p. 37.

${ }^{13}$ Seyyed Hossein Nasr, In Search of The Sacred, (Colorado: Preager), p. 168 
so that the soul cannot move material potentials such as vision, hearing, smell, touch and feeling ${ }^{14}$.

The existence of spirit is very closely related to the soul. The soul which is the essence of man is positioned between two ontological realities, namely, spiritual in the form of spirit, and material body. The human soul moves in a certain direction the movement depends on the use of its potential. many philosophers who mentioned the concept of the process of movement of the potential of the soul, among others, the most famous are al-Ghazali and Ibn Miskawaih in his book Kimiya al-Sa'adah and Tahạib alAkhlak, quoted by Nur Hanim. Both of them explain in detail the potential of the soul which consists of three core faculties, among others: al-quwwah al-natiqah, al-quwwah al-ghadabiyah, and alquwwah al-shahwiyah. While al-Ghazali termed it with the terms nafs al-insaniyyah, nafs al-hayawaniyyat and nafs al-hayawaniyyah. Each of these three potentials has two positions: advantages and disadvantages of al-Tafīit and Al-Ifrāt. Al-Ghazali and Ibn Miskawaih both used the middle way doctrine as the main position of al-Wasat. Thus, the soul that succeeds in using its potential is the soul that gets the middle position of every potential including: al-hikmah, al-syaja'ah, and al-iffah ${ }^{15}$. This third state of the soul can deliver humans to the center of their energy in the form of spirit and get the highest awareness of the universe.

The highest consciousness becomes the culmination of the true human state. By it one can see the reality of the world as it is. This ability comes from the human nature which is part of God. This is justified by the process of creating the cosmos that Muslim philosophers refer to as emanation ${ }^{16}$, or Suhrawardi's theory which specifically states that humans are part of God's light graded from immaterial peak light to material peak (darkness) ${ }^{17}$, so does Mulla Sadra who mentions that humans are derived from the reality of the

${ }^{14}$ Muhammad Iqbal Irham, Menghidupkan Spiritualitas islam: Kajian terhadap Konsep Hudūr Ibn Arabi, p. 30-32.

${ }^{15}$ Nur Hanim, "Pendidikan Akhlak: Komparasi Konsep Pendidikan Ibn Miskawaih dan al-Ghazali” Journal of Ulumuna, vol. 18. no. 1, (2014), p. 27.

${ }^{16}$ Seyyed Hossein Nasr, History of Islamic Philosophy, (New York: Routledge), p. 446.

17 Peter Groff \& Oliver leaman, Islamic Philosophy A-Z (Edinburg: Edinburg University Press), p. 201. 
one essential. It becomes an explanatory source of other realities ${ }^{18}$. These theories show human status that has the characteristics of God because it is created from His essence so that humans are enabled by God to get the highest awareness. Regarding the process of obtaining the highest awareness of knowledge, Nasr in his Knowledge and The Sacred book states:

The answer of tradition is that the twin source of this knowledge is revelation and intellection or intellectual intuition which involves the illumination of the heart and the mind of man and the presence in him of knowledge of an immediate and direct nature which is tasted and experienced, the sapience which the Islamic tradition refers to as presential knowledge" (al-ilm al-hudūūr) ${ }^{19}$.

With the explanation above, it can be understood that spirituality in terms of its characteristics requires that it be pursued through transcendent things. This can be seen from its essence which is also transcendent.

\section{The Concept of al-Ilm al-Hudūni and al-Ilm al Husūli}

These two concepts of knowledge (al-Ilm al-huḍūri and alIlm husūli) will lead to a contextual understanding of the possible knowledge of human beings, so that this needs to be discussed specifically. What distinguishes between hudūri and hushuli (the science of success) is whether or not the intermediary is used in presenting knowledge. Hudūri does not at all use mental intermediaries to obtain knowledge while hushuli uses mental intermediaries ${ }^{20}$. The process of acquiring knowledge by presenting it in self is named by some Muslim philosophers as al-Ilm al-Hudūìi which means to present it self.

Thus, the characteristic nature of al-Ilm al- Hudūri is a manifestation of knowledge that is known by the knower (subject), which then distinguishes it from husūli where what is present is

${ }^{18} \mathrm{Sadr}$ al-Din Shirazy, Mazāhir al-Ilāhiyah fì al-Asrar al-Ulūm alKamāliyyah. (Teheran: Sadra Foundation of Islamic Philosophy), p. 15.

${ }^{19}$ Seyyed Hossein Nasr, Knowledge and the Sacred, (New York: State University of New York), p. 119

${ }^{20}$ Muhsin Labib, Pemikiran Ayatullah M.T Misbah Yazdi, (Jakarta: Sadra Press), p. 158 
mahiya or the divinity of that knowledge. ${ }^{21}$ The form as things obtained by this method ontologically cannot be explained by universal principles (Kulliyat al-Khams). This is because there are no conditions for fulfilling an explanation or definition for a form which also shows the clarity of the concept of being. ${ }^{22}$

These characteristics, cause the validity of the knowledge cannot be denied, and experience it is the only solution to know its essence. In this context Muhammad kamal said in Mulla Sadra's Trancendent Philosophy:

Knowledge by presence has characteristics of its own that distinguish it from knowledge by representation. It is direct and unmediated by concepts, and indubitable. Since it is neither representational nor non-propositional, it is neither false nor true. Its truth is beyond empirical verification and assertion in propositions. Furthermore, in knowledge by presence the distinction between intelligent and intelligible disappears. The knower and the known object unite as one being". Finally, this type of knowledge is beyond the domain of demonstration by reason. The intellectual intuition of the source of knowledge by presence becomes a mystical tool of cognition (al-Kashf). ${ }^{23}$

Thus, the acquisition of al-Ilm al-Husuli both through empirical verification and analysis of propositions cannot be used to find out this knowledge. The characteristics of this disclosure of science which ultimately necessitates a person to experience firsthand and use the path of the Sufis to be able to reach it, where intuitive witnessing based on the sanctity of the soul becomes the condition. ${ }^{24}$

\section{The Problem of HTI's Epistemological Reasoning}

The core claim that HTI has built in its epistemology lies in the meaning of the process of thinking. He defines it as "proses

${ }^{21}$ Abulfazel Kiyashemshaki, "Interaksi Filsafat Islam dan Irfan dalam Hikmah Muta'alliyah” Journal of Khanz Philosophia, vol. 4. no. 1, (2014), p. 65. Fikr), p. 16 .

${ }^{22}$ Muhammad Husain Ṭabāṭabā'i, Bidāyah al-Hikmah, (Qom: Dar al-

${ }^{23}$ Muhammad Kamal, Mulla Sadra's Transcendent Philosophy, (USA: Ashgate), p. 97.

${ }^{24}$ Haidar Bagir, Pengantar Epistemologi Tasawuf, p. 121. 
memindahkan fakta melalui panca indera ke dalam otak". ${ }^{25}$ In this context it can be understood that sensory factual data is the basis of his knowledge which is also a requirement that something process is said to think. The non-factual data is considered merely fantasy because according to him it does not have reality. ${ }^{26}$ The factual reality that can be justified for him only applies to material objects. ${ }^{27}$

This perspective on the epistemological side is in line with the notion of empiricism which also makes sensory data as a source of knowledge "Empiricism is the theory that experience rather than reason is the source of knowledge" ${ }^{28}$ And ontologically it leads to materialism by definition. "Materialism is a name given to a family of doctrines concerning the nature of giving to a primary position and dependent reality or even none at all". ${ }^{29}$ The characteristics of these two views require limited reality. On objects that can be sensed as well as materialistic. This certainly has implications for disclaiming a variety of perspectives which are non-materialistic sources of knowledge, such as philosophy, tasawuf and kalam science as well as other sciences. This point of view makes no difference whatsoever with empirical western thinkers as well as materialist. ${ }^{30}$ The axiological attitude that they plant certainly negates the entire reality that is not sensed and non-material. In the end, the two things will become a world view in seeing the whole reality and categorizing it as non-sense even at a certain level is considered non-existent. In the context of HTI's viewpoint, they ultimately classify knowledge other than the sensed and non-material in the category of fantasy not a science:

Meskipun banyak pengetahuan yang dihormati dan dipastikan sebagai akidah- berupa objek-objek yang tidak bisa dipikirkan - maka definisi akal dan menjadikan metode rasional yang dijadikan asas berpikir, menuntut bahwa objek yang bukan fakta atau tidak bisa diindera, tidak bisa dijadikan objek proses berpikir. Proses yang

${ }^{25}$ Taqiyuddin An-Nabhani, At-Tafkir, p. 52.

${ }^{26}$ Ibid., p. 53.

${ }^{27}$ Ibid., p. 22.

${ }^{28}$ Donald. M. Borchert (ed.), Ecnyclopedia of Philosophy, p. 213.

${ }^{29}$ Ibid., p. 5.

${ }^{30}$ Cipta Bakti Gama, Filsafat Jiwa: Dialektika Filsafat Islam dan Filsafat Barat Kontemporer, (Malang: Pustaka Sophia 2018), p. 30. 
belarngsung juga tidak bisa dikatakan aktivitas berpikir. Contohnya, pendapat tentang Akal Pertama, Akal Kedua, dan seterusnya (filsafat Neo-Platonisme-peny) hanyalah sekadar fantasi (khayalan) dan asumsi semata, karena tidak merupakan fakta yang inderawi dan tidak termasuk objek yang mungkin dapat diindera. Artinya, proses berkhayallah yang telah mengkhayalkan atau mengasumsikan adanya asumsi-asumsi teoretis itu, yang mengantarkan pada berbagai kesimpulan. Fantasi semacam ini jelas bukan aktivitas berpikir. Berkhayal bukanlah proses berpikir. Bahkan seluruh asumsi yang ada-meskipun asumsi-asumsi dalam matematika - bukanlah proses berpikir dan bukan aktivitas berpikir. ${ }^{31}$

Besides, that the reason for his rejection of Sufism and philosophy lies in the source of his knowledge which does not use the al-Qur'an and al-Sunnah. ${ }^{32}$

This disclaimer completely closes the space for Sufism as one of the sciences that can transform the values of love and noble character $^{33}$. This is through intuitive disclosure where his perspective sees the similarity of the degree of all creatures besides Al-Haq $(\mathrm{God})^{34}$. But in certain literature such as, Min Muqawwamat Nafsiyah al-Istāmiyah, HTI recognizes Sufism spirituality in the form of materialistic empiricism. This is seen in the measurement of one's spiritual degree experience with dzahiri worship ${ }^{35}$. This is so, that a person's spiritual experience can be measured from the level of his or her final devotional worship which at a certain level can justify one's

${ }^{31}$ Taqiyuddin An-Nabhani, At-Tafkir, p. 53-54.

${ }^{32}$ Ahmad Musyafiq, "Spiritualitas Kaum Fundamentalis", p. 58-59.

${ }^{33}$ Seyyed Hossein Nasr, The Garden of Truth: The Vision and Promise of Sufism, Islam's Mystical Tradition, (New York: HarperOne. 2007), p. 82. See also Azadar Hussain Khwaja, dkk, "Enlightened Message of Sufism Towards Peace and Harmony", Journal of Mystic Thoughts: Research Journal of Sufism and Peace Supplementary Edition, vol. 1. no. 1, (2015), p. 47. See also Muhammad Irfan, dkk, "Psychological Healing in Pakistan: From Sufism to Culturally Adapted Cognitive Behaviour Theraphy", Journal of Contemporary Psychotherapy, vol. 47. no. 2, (2017), p. 121. See also Zuleyha Keskin, "Inner Peace in Islam", Journal of Australian Islamic Studies, vol. 1. no. 1, (2016), p. 27.

${ }^{34}$ Shadr al-Muta'alihin Shirazi, Masyāir, (Tehran: Tahouri Publisher. 1984), p. 53.

${ }^{35}$ Hizbut Tahrir, Min Muqawwamat Nafsiyah al-Islāmiyah, (Beirut: Dar al-Amanah 2004), p. 8-10. 
piety even though taking radical actions by relying solely on the final quantification of worship.

\section{E. Sadrian's Integrative Epistemology}

The main claim in Sadra's integrative epistemology lies in the possibility of Hudhuri's knowledge in the form of revealing the inner spiritual to capture the knowledge of external objects outside of the subject of the knower. This also became a distinction between Sadra and other Islamic philosophers. Historically his thoughts on the knowledge of Hudūri were a direct response from Ibn Sina who previously believed that the knowledge of Hudūri only applies to mental states such as hunger thirst and other personal conditions. ${ }^{36}$

Thus, it is clear that the only alternative is to know the outside objective reality only with al-Ilm al-Husūli. Husūli in the form of knowledge is divided into two, namely: particular (which applies only to one object) and is universal (which applies more than one object). Particular knowledge is generally obtained through the senses while universal knowledge is the result of abstraction from particular knowledge acquired through the senses ${ }^{37}$. By this, so in Islamic paratetism, philosophical knowledge rests entirely on the results of abstractions obtained through the senses. It also indirectly says the senses as a source of philosophical knowledge. Therefore, it is appropriate that Ibn Sina as a well-known figure in Islamic paripatetism summarizes this series of facts in his dictum "man faqada hissan faqada ilman ". That is, a human who loses one of his senses automatically loses the knowledge gained from. ${ }^{38}$

In its development, Islamic paripatetism philosophy, especially Sinaian, began to highlight Irfani's knowledge and intuitive witnessing, but according to him, this knowledge (intuitive) with discursive argumentative relations had nothing to do with each other. On this basis then Islamic paratetism is weak in dealing with

${ }^{36}$ Abulfazel Kiyashemshaki, "Interaksi Filsafat Islam dan Irfan dalam Hikmah Muta'alliyah", p. 63

${ }^{37}$ Abd al-Jabbar Rifa'I, Mabādi al-Falsafah al-Islāmiyah, (Beirut: Dar alhadi. 2001) Vol. 2, p. 7.

Vol. 3, p. 220.

${ }^{38}$ Abu Ali Sina, Al-Syifa, (Qom: Ayatullah Mar'ashi Najafi Library. 1984) 
problems in the field of theology and the domain of reality which is not sensed or in terms of the unseen Qur'an and natural occultation. ${ }^{39}$

Sadra's philosophy rests on this weakness in building his philosophical epistemology and pressing deeply into the weaknesses of the philosophy of Islamic paripatetism, especially Sinaian. Although we mentioned earlier that Sinaian highlights intuitive knowledge especially in the Namath book in the last chapter, it does not accommodate it in an epistemological system. So that practically this system loses intuitive witnessing as a source of knowledge. ${ }^{40}$

This is different from Sadra's philosophy which does not only limit al-Ilm al-Hudhuri to experiences of the state of the soul, but rather accommodates it as a tool to be able to know objective reality. In this case, Sadra uses the same method carried out by the urafa or Sufis in knowing the objective reality, namely by intuitive witnessing ${ }^{41}$. Therefore, the knowledge gained as a system of philosophy is not only based on the senses but intuitive spiritual experience. On this basis, Sinaian's ontology is different from Sadrian, where Sinaian in his best quality only gets knowledge about the state of things, as is the case with Sadrian who obtains the form of something.

Whereas in the context of the use of rationality, in principle Sadrian's philosophy had no difference with previous Islamic philosophers ${ }^{42}$. Rationality in Sadrian's version was finally used as a medium to report on spiritual experiences he gained through the inner disclosure of the science of hudūri ${ }^{43}$. This means that the use of aspects of rationality is at the level of philosophical evidence based on intuitive disclosure as a source of knowledge. At this point Sadra's philosophy is more likely to accurately know objective reality, given what is abstracted by reason is the existensial experience of

${ }^{39}$ Abulfazel Kiyashemshaki, "Interaksi Filsafat Islam dan Irfan dalam Hikmah Muta'alliyah", p. 64.

${ }^{40}$ Abulfazel Kiyashemshaki, "Interaksi Filsafat Islam dan Irfan dalam Hikmah Muta'alliyah", p. 64.

${ }^{41}$ Shadr al-Muta'alihin Shirazi, Syawāhid al-Rubūbiyyah. (Markaz-e Nashr Daneshgahi), p. 134. p. 122.

${ }^{42}$ Cipta Bakti Gama, Filsafat Jiwa: Dialektika Filsafat Islam dan Filsafat,

${ }^{43}$ Haidar Bagir, Pengantar Epistemologi Tasawuf, p. 89. 
something. ${ }^{44}$ So, it is appropriate for Sadra to compile this concept through his dictum "Man lā kasyfa lah, là ilma lah" (person who does not reach disclosure are essentially lacking in true knowledge). ${ }^{45}$

The textuality in the form of the al-Qur'an and al-Sunnah is at the level of guidance in preparing one's soul to experience a spiritual journey. One of these seems to be the interpretation in Annur verse 35:

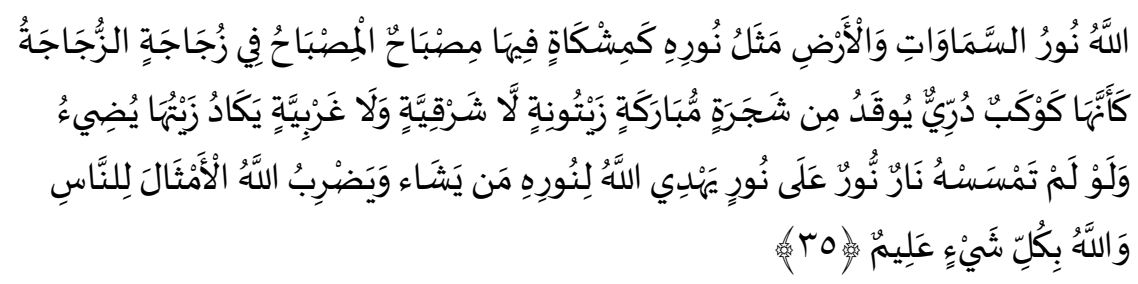

Sadra in this verse interprets the word misykāt as heart (qalb). ${ }^{46}$ According to him, the heart of a believer will receive emanations from God in the form of $n \bar{u} r$, and when he gets $n \bar{u} r$, the emission of knowledge from God is opened to him. Sadra reinforced his revelation regarding this matter by quoting the hadith of the Prophet in line with the verse al-Qur'an Surat al-Zumar verse 22:

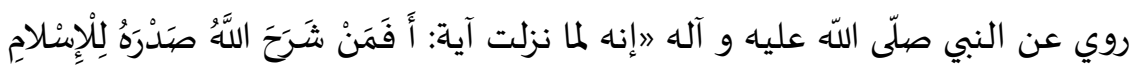

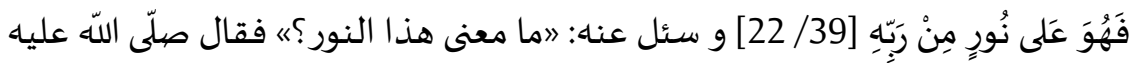

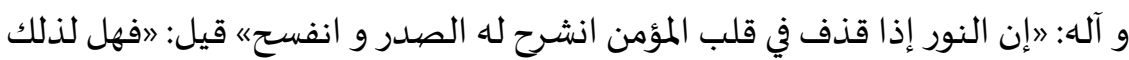

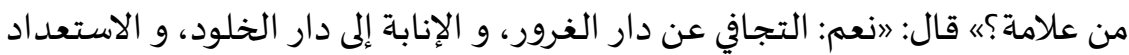
للموت قبل نزولهه

In this hadith Rasulullah's friend asks about the meaning of the word nur in the verse above, then the prophet answers that actually nur when attached to the heart of a believer he becomes roomy and open. Next friend asks if there is a sign? The Prophet replied, Yes, that is the heart that is capable of releasing from a world

${ }^{44}$ Ibid., p. $90-91$.

${ }^{45}$ Shadr al-Muta'alihin Shirazi, Syawāhid al-Rubūbiyyah fi Manāhij alSulūkiyyah, p. 14.

${ }^{46}$ Shadr al-Muta'alihin Shirazi, Tafsīr al-Qur'an al-Karīm, (Qum: Bidar Publisher 1987), p. 351. 
full of deception and hurrying back to the hereafter and preparing for death before his death. ${ }^{47}$

Not only that, textuality is also used as a measure of harmonization between religion and philosophy. He said that it was impossible for the right and pure white Shari'a laws to clash with self-knowledge ${ }^{48}$. At this point Sadra is in harmony with the goals of other Islamic philosophers, because one of the main mission of Islamic philosophy is to harmonize between religion and philosophy. By this it can be understood that Sadra integrates these three methods in building his philosophical system.

\section{F. From Sadra's Integrative Epistemology to the Deradicalization of HTI}

Deradicalization through integrative epistemology of Sadrian can occur at the point of receiving the source of intuitive spiritual knowledge or Hudüri knowledge as the previous knowledge base, which HTI rejects the source of knowledge while sticking to the principles of empiricism and materialism. As previously discussed, the source of intuitive spiritual knowledge provides a basis for understanding what constitutes something. General understanding of form or the originator of the popular, Ibn Arabi at a certain level requires an understanding that all beings other than al-Haq have the same status of being ${ }^{49}$.

In Sadrian's perspective this was confirmed by philosophical proof that human relations with God are al-Ayn al-Rābith ${ }^{50}$. Sadra's argument regarding the status of the existence of God and mankind began in his response to the earlier philosophers who believed that $m a ' l \bar{l} l$ (consequence) in relation to illat (cause) was independent by others (fī nafsihi lī ghairihi). This is explained by Ibn Sina, because the status of being other than God is imitated (possible), which in order for him to become obligatory, requires the obligation of al-

${ }^{47}$ Ibid., p. 351.

${ }^{48}$ Kerwanto, "Pemikiran Filosofis Sadra dalam Tafsir al-Quran al-Karīm", Journal of Khanz Philosophia, vol. 2. no. 4. (2014), p. 129.

${ }^{49}$ Ali Akbar, "Looking at Ibn Arabi's Notion of Wahdat al-Wujūd as a Basis for Plular Path to God", Journal of Islamic Studies and Culture. vol. 4. no. 1. (2016), p. 46-47.

${ }^{50}$ Shadr al-Muta'alihin Shirazi, Tafsìr al-Qur'an al-Karim, p. 63. 
wujü $d$ as a cause for its existence. This then makes the benchmark of dependence on the status of $m a{ }^{\prime} l u l$ to the $i l a t^{51}$

Sadra departed from this point to justify his claim that $m a^{\prime} \bar{l} \mathbf{1}$ in his relationship with ilat was not independent (fī ghairihi) which he was the form of Ayn al-Räbith or his form was identical to his dependence. He (Sadra) built his argument by negating the views of the previous philosophers who stated that ma'lul (consequence) was not a form given by the ilat (cause) nor was it an embodiment given by ilat or more simply that ma'lul had an independent ${ }^{52}$.

The consequence of understanding the first negation (ma'lūl is not a being given by illat) then in a sense there are two possibilities: first $m a^{\prime} l \bar{u} l$ (consequence) exists before being given a form or the second exists after being given a form. The first possibility is certainly not justifiable because if there is before the giving of form then it does not need an illusion because it can already exist with the intermediary of being. This is likely to contradict the agreed assumption that ma'lul needs knowledge in the process of adopting it. The second assumption if ma'lul (effect) exists after giving form, consequently there is a time when ma'lüldoes not exist. It is also not possible to remember that both exist together (cause and effect), so, ma'lul (effect) must be present at all times. The second form of negation (ma'lul is not an embodiment given by the illusion) has implications for the impossibility that something manifests itself ${ }^{53}$.

This also leads to the understanding that al-Haq is the only form (al-Wujūd al-Syakhsiyah) ${ }^{54}$. Thus, it can be understood that the intuitive witnessing epistemology which undergoes directly the form of knowledge leads to the understanding that the form other than al$\mathrm{Haq}$ is needed by it. This certainly makes a paradigm that seeks to understand and even appreciate the understanding of others, given that all realities other than $\mathrm{Al}-\mathrm{Haq}$ are dependent. ${ }^{55}$

${ }^{51}$ Abu Ali Sina, al-Isyarāt wa al-Tanbihāt, (Qum: Nasr al-Balaghah. 1996), p. 97.

${ }^{52}$ Shadr al-Muta'alihin Shirazi, Tafsīr al-Qur'an al-Karìm, vol. 1, p. 64.

${ }^{53}$ Ibid., p. 63.

${ }^{54}$ Shadr al-Muta'alihin Shirazi, Masyāāir, p. 53.

${ }^{55}$ Shadr al-Muta'alihin Shirazi, al-Hikmah Muta'alliyah fīi al-Asfar alAqliyyah al-Arba'ah, p. 14 
This base then becomes a weapon in de-radicalizing the understanding of HTI which limits reality to sensory and materialistic matters. In addition, the commitment of the Qur'an and the Sunnah held by HTI as a basis for religion is not even an integral part of Sadrian's philosophical system. This means that conceptually in Sadrian's philosophical system there is no necessity to deny the two sources of knowledge in the form of rationality and spirituality as a condition for purely holding to the Qur'an and al-Sunnah.

In the end the integration of Sadrian's epistemology of philosophy based on intuitive spiritual disclosures reported through rational methods led to the understanding of the unity of reality and the need for the whole reality of reality other than al-Haq. This is to understand that everyone has the same existential status and should appreciate even saving the feeling of wanting to know the truth of others. At the same time committed to two main sources in Islam in the form of the Qur'an and al-Sunnah which were the main reasons for HTI's rejection of philosophy and Sufism.

\section{G. Conclusion}

With the explanation above, it can be understood that using the integrative method of Sadrian can counteract the radical understanding of HTI in the form of acceptance of intuitive witnessing as a source of knowledge, and rationality as a tool to report the intuitive experience while remaining committed to the Qur'an and al-Sunnah. [.]

\section{References}

An-Nabhani, Taqiyuddin. At-Tafkir, translated by Taqiyuddin AsSibā'I, Bogor: Hizbut Tahrir, 1973.

An-Nabhani, Taqiyuddin. Mafāhim At-Tafkir, translated by Abdullah, Jakarta: Hizbut Tahrir, 2001.

Ali Akbar. "Looking at Ibn Arabi's Notion of Wahdat al-Wujūd as a Basis for Plular Path to God". Journal of Islamic Studies and Culture, vol. 4, no. 1 (2016). 
Fadhlu Rahman, dkk.

Bagir, Haidar. Epistemologi Tasawuf: Sebuah Pengantar. Bandung: Mizan, 2017

Borchert, Donald M. Encyclopedia of Philosophy. New York: Thompson Gale Corporation, 2006

Gama, Cipta Bakti. Filsafat Jiwa: Dialektika Filsafat Islam dan Filsafat Barat Kontemporer. Malang: Pustaka Sophia, 2018

Groff, Peter. S \& Leaman, Oliver. Islamic Philosophy A-Z. Edinburg: Edinburg University Press, 2007.

Hanim Nur. "Pendidikan Akhlak: Komparasi Konsep Pendidikan Ibnu Miskawaih dan al-Ghazali". Ulümuna, vol. 18, no. 1 (2014).

Ihsanuddin. Jalan Panjang Pemerintah Bubarkan HTI, Kompas, 2018

Irfan, Muhammad dkk. "Psychological Healing in Pakistan: From Sufism to Culturally Adapted Cognitive Behaviour Theraphy". Journal of Contemporary Psychotherapy, vol. 47, no. 2 (2017).

Labib, Muhsin. Pemikiran Filsafat Ayatullah M.T. Misbah Yazdi. Jakarta: Sadra Press, 2011.

Kamal, Muhammad. Mulla Sadra's Trancendent Philosophy. USA: Ashgate, 2006.

Kerwanto, "Pemikiran Filosofis Sadra dalam Tafsīr al-Qur'an alKarīm: Surah al-A'la". Khanz Philosophia. vol. 4, no. 2, (2014).

Keskin, Zuleyha. "Inner Peace in Islam", Australian Journal of Islamic Studies, vol 1. no. 1, (2016).

Khwaja, Azadar Hussain dkk. "Enlightened Message of Sufism Towards Peace and Harmony". Research Journal of Sufism and Peace Supplementary Edition, vol. 1. no. 1 (2015).

Kiashemshaki, Abulfazel. "Interaksi Filsafat Islam dan Irfan dalam Hikmah Muta'aliyah". Journal of Kanz Philosophia, vol. 4, no. 1 (2014).

Lufaefi. "Rekontruksi Jargon Formalisasi Syari'at: Upaya Menjaga Persatuan dalam Bingkai Keberagamaan". Journal of AlA'raf, vol. 14. no. 1, (2017).

Mufid, Fathul. "Radikalisme Islam dalam Perspektif Epistemologi". Journal of Addin, vol. 10, no. 1, (2016). 
Musyafiq, Ahmad. "Spiritualitas Kaum Fundamentalis". Journal of Walisongo, vol. 20, no. 1, (2012).

Nasr, Seyyed Hossein. The Garden of Truth: The Vision and Promise of Sufism, Islam's Mystical Tradition. New York: HarperOne, 2007.

------. History of Islamic Philosophy. New York: Routledge, 1996.

------. In Search of the Sacred. Colorado: Praeger, 2010.

------. Knowledge and the Sacred. New York: State University of New York Press, 1989.

Nawab, Mohamed \& Mohamed Osman. Reviving the Caliphate in the Nusantara: Hizbut Tahrir Indonesia's Mobilization Strategy and Its Impact in Indonesia. Singapura: Nanyang Technological University, 2009.

PPIM (Pusat Pengkajian Islam dan Masyarakat). Survey Nasional tentang Sikap keberagamaan di Sekolah dan Universitas di Indonesia. Jakarta: PPIM UIN Jakarta, 2017.

Rahman, Fazlur. Islam and Modernity. Chicago: Chicago University Press, 1962.

Rifa'I, Abd al-Jabbar. Mabadi al-Falsafah al-Islämiyah. Beirut: Dar al-Hadi, 2001.

Shirazi, Sadr al-Muta'alihin. Al-Hikmah al-Muta'aliyah fĩ al-Asfar al'Aqliyyah al-Arba'ah. Beirut: Dar Ihya' al-Turath al-'Arabi, 1981.

-------. Al-Syawahid al-Rububiyyah. Markaz-e Nashr-e Daneshgahi (Academic Publishing Center), $1401 \mathrm{H}$.

------. Tafsīr al-Qur'an al-Karìm. Qum: Bidar Publisher, 1987.

------. Masyā'ir. Tehran: Tahouri Publisher, 1984.

------. Mazāhir al-Ilāhiyyah fì al-Asrar al-Ulūm al-Kamāliyyah. Tehran: Sadra Foundation of Islamic Philosophy, 1999.

Sina, Abu Ali. Al-Isyārat wa al-Tanbihāt. Qum: Nashr al-Balaghah, 1996.

------. Al-Syifa. Qom: Ayatollah Mar'ashi Najafi Library, 1984.

Tahrir, Hizbut. Min Muqawwamat Nafsiyah al-Islāmiyah. Beirut: Dar al-Ammah, 2004.

Thabātabā'I, Husain Muhammad. Bidāyah al-Hikmah. Qom: Dar alFikr, $1387 \mathrm{H}$. 
Fadhlu Rahman, dkk.

Tibi, Bassam, Islamism and Islam. London: Yale University Press, 2012.

Yazdi, Taqi Misbah. Philosophical Instruction: An Introduction to Contemporary Islamic Philosophy. New York: Global Publication, 1999.

Yunanto, Sri, \& Damayanti, Anggel, The Root and Causes of Nexus Militant Islamic Movements in Indonesia: Case Studies of Darul Islam and Jemaah Islamiyah. Asia Pacific Studies, vol. 1. no. 1, (2017). 